\title{
Sensitive Amperometry of 4-Aminophenol Based on Catalytic Current Involving Enzymatic Recycling with Diaphorase and Its Application to Alkaline Phosphatase Assay
}

\author{
Seiki YamaguchI*, Shogo Ozawa**, Tokuji IKEdA** and Mitsugi Senda** \\ *Department of Chemistry, Osaka Medical College, Sawaragi, Takatsuki, Osaka 569, Japan \\ **Department of Agricultual Chemistry, Kyoto University, Kyoto 606-01, Japan
}

Keywords Alkaline phosphatase, amperometry, catalytic current, enzymatic recycling, diaphorase, 4-aminophenol

Alkaline phosphatase is a common enzyme used in electrochemical enzyme immunoassays, with phenyl phosphate as a substrate. The phenol compound produced by the enzyme-catalyzed hydrolysis of phenyl phosphate is measured by oxidative amperometry. Recently, the use of 4-aminophenyl phosphate as a substrate in these assays has been advocated and extensively studied by several authors. ${ }^{1-6}$ In this note we report that 4-aminophenol, the hydrolysis product of 4-aminophenyl phosphate, can be amperometrically detected at concentration levels as low as $10^{-10} \mathrm{M}$ $\left(\mathrm{M}=\mathrm{mol} \mathrm{dm}^{-3}\right)$ by the principle of polarographic catalytic current ${ }^{7,8}$, in which enzymatic recycling ${ }^{9}$ with a redox enzyme (that is, diaphorase) is involved; the sensitivity of the electrochemical assay of alkaline phosphatase is greatly improved by this method.

Alkaline phosphatase (EC 3.1.3.1, Lot No. 06290) was purchased from Toyobo Co., Ltd. The enzyme was dissolved with a $1 \%$ bovine serum albumin (BSA) solution containing $0.25 \mathrm{mM} \mathrm{MgCl}_{2}$ and stored in a refrigerator. Diaphorase (EC 1.6.99.-, Type I) from Bacillus stearothermophillus was a gift from Unitika Ltd. The enzyme was dissolved with a $1 \%$ BSA solution. 4Aminophenyl phosphate (PAPP, Aldrich Chemical Co., Inc.), 4-aminophenol (PAP, Wako Pure Chemical Industries, Ltd.) and NADH (reduced form of nicotinamide adenine dinucleotide, Oriental Yeast Co., Ltd.) were used without further purification. PAPP was dissolved in a $0.1 \mathrm{M}$ carbonate buffer ( $\mathrm{pH}$ 10.3) containing $0.25 \mathrm{mM} \mathrm{MgCl}$, immediately before use. PAP was dissolved in a $0.02 \mathrm{M}$ acetate buffer ( $\mathrm{pH} 4.5$ ). Other chemicals were of analytical-reagent grade.

The working electrode was a glassy carbon disk electrode $(\phi=0.3 \mathrm{~cm})$. The electrode was polished to a mirror-like finish with $0.05 \mu \mathrm{m}$ alumina, followed by through rinse with deionized water in an ultrasonic bath. The counter electrode was a platinum electrode. The potentials were measured against an $\mathrm{Ag} / \mathrm{AgCl}$ (sat. $\mathrm{KCl}$ )

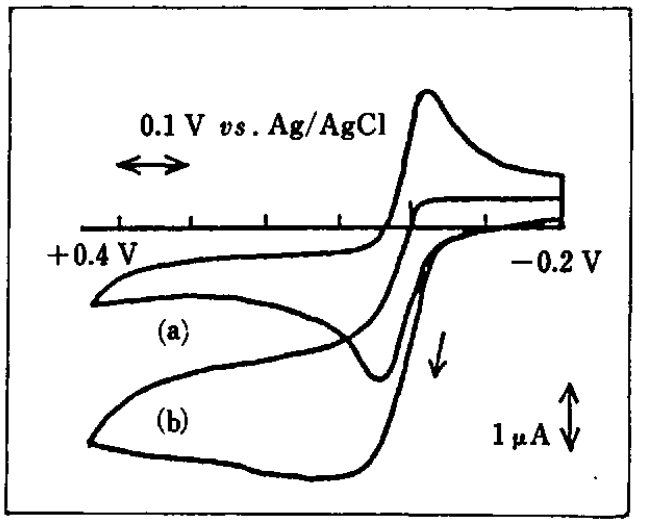

Fig. 1 Cyclic voltammograms of $4 \times 10^{-4} \mathrm{M}$ PAP in $0.1 \mathrm{M}$ tris-buffer of pH 8.5 without (a) and with (b) $3.3 \times 10^{-8} \mathrm{M}$ diaphorase and $10^{-3} \mathrm{M}$ NADH. Potential was scanned at $10 \mathrm{mV} \mathrm{s}^{-1}$ from $-0.2 \mathrm{~V}$.

reference electrode. Electrochemical measurements were carried out in an $\mathrm{H}$-type plexiglass cell with a sample volume of $0.4 \mathrm{ml}$, thermostated at $37 \pm 0.3^{\circ} \mathrm{C}$, with a potentiostat (Yanaco polarographic analyzer P-1000) connected with an $X-Y$ recorder (Yokogawa Modal 3025).

Figure 1 shows cyclic voltammograms of $10^{-4} \mathrm{M}$ PAP in a $0.1 \mathrm{M}$ tris-buffer solution of $\mathrm{pH} 8.5$ without (a) and with (b) $3.3 \times 10^{-8} \mathrm{M}$ diaphorase and $10^{-3} \mathrm{M}$ NADH. The results clearly show that the anodic current due to the oxidation of PAP to 4-quinone imine (PQI),

$$
\mathrm{PAP} \longrightarrow \mathrm{PQI}+2 \mathrm{H}^{+}+2 \mathrm{e}^{-}
$$

is greatly amplified by enzymatic recycling:

$$
\mathrm{PQI}+\mathrm{DIP}(\mathrm{red}) \stackrel{k_{2}}{\longrightarrow} \mathrm{PAP}+\mathrm{DIP}(\mathrm{ox})
$$




$$
\mathrm{DIP}(\mathrm{ox})+\mathrm{NADH} \longrightarrow \mathrm{DIP}(\mathrm{red})+\mathrm{NAD}^{+} .
$$

Here, DIP(red) and DIP(ox) are the reduced and oxidized forms of diaphorase, respectively. Theoretical cosideration shows ${ }^{7,8,10}$ that the (amplified) catalytic current, according to Eqs. (1) - (3), should increase linearly with the concentration of PAP, as well as with the square root of the concentration of diaphorase. These theoretical predictions were experimentally proved to be valid, giving the bimolecular reaction rate constant as $k_{2}=1.9 \times 10^{9} \mathrm{M}^{-1} \mathrm{~s}^{-1}\left(\mathrm{pH} 8.5,25^{\circ} \mathrm{C}\right)$ for Eq. (2). ${ }^{11}$

\section{Electrochemical determination of PAP}

Calibration curves for PAP were prepared in order to determine the detection limits. Four microliters of the diaphorase solution $\left(3.3 \times 10^{-6}\right.$ or $\left.3.3 \times 10^{-4} \mathrm{M}\right)$ and $4 \mu \mathrm{l}$ of $0.1 \mathrm{M}$ NADH were syringed successively into $382 \mu \mathrm{l}$ of $0.1 \mathrm{M}$ tris-buffer in an electrolysis cell to make the basal solution. An aliquot (usually $10 \mu \mathrm{l}$ ) of the standard solution of PAP was syringed in the basal solution, and the mixture was stirred with a magnetic rotor for a few seconds. The anodic current at $+0.15 \mathrm{~V}$ was recorded. A stationary current response was observed immediately after each addition of the PAP solution. A linear calibration curve was confirmed for a concentration range of PAP between $5 \times 10^{-9}$ and $1 \times 10^{-7} \mathrm{M}$ in the basal solution containing $3.3 \times 10^{-8} \mathrm{M}$ diaphorase. The relative standard deviation at $1 \times 10^{-8} \mathrm{M}$ PAP was $5.1 \%$ $(n=10)$. Also, a linear calibration curve was confirmed for the concentration range of PAP between $1 \times 10^{-9}$ and $1 \times 10^{-8} \mathrm{M}$ in the basal solution containing $3.3 \times 10^{-6} \mathrm{M}$ diaphorase with the slope of $4.6 \mathrm{nA} / 10^{-8} \mathrm{M}$ PAP and the noise level (base current) of $0.07 \mathrm{nA}$. The experimental detection limit defined as $3 \times$ noise/slope of calibration curve $^{6}$ ) was $5 \times 10^{-10} \mathrm{M}$. This study is being continued so as to further improve the detection limit.

\section{Alkaline phosphatase assay}

One microliter of the alkaline phosphatase solution was syringed into $49 \mu$ of a carbonate buffer ( $\mathrm{pH} 10.3$ ) containing $0.25 \mathrm{mM} \mathrm{MgCl}_{2}$ and $0.1 \mathrm{M}$ PAPP to make an assay mixture thermostated at $37^{\circ} \mathrm{C}$. After a fixed time (usually $10 \mathrm{~min}$ ) for the enzymatic reaction, an aliquot $(10 \mu \mathrm{l})$ of the assay mixture was syringed out and added into the basal solution in an electrolysis cell, the mixture was then stirred for a few seconds. The oxidation current at $+0.15 \mathrm{~V}$ was measured. It has been shown that the detection limit of alkaline phosphatase by the present electrochemical method, when the basal solution containing $3.3 \times 10^{-6} \mathrm{M}$ diaphorase was used, was $1 \times 10^{-7}$ units (equivalent to $4 \times 10^{-19}$ moles) in a $50 \mu \mathrm{l}$ assay mixture. The sensitivity of the present method is comparable to that of the chemiluminescent method. ${ }^{12}$

The experimental results show that the present method of the amperometric detection of alkaline phosphatase activities can be the basis for developing sensitive electrochemical enzyme immunoassays using alkaline phosphatase catalysis. This method also appears promising for enzyme immunoassays based on other enzyme catalysis, such as galactosidase catalysis. Also, other redox enzymes in the place of diaphorase, like glucose oxidase, as well as other redox substrates, are being investigated.

The authors are grateful to Professor A. Tsuji of Showa University for his interest in this work and to Dr. S. Satomura of Wako Pure Chemicals Industries, Ltd. for his dicussion. Thanks are also due to Unitika Ltd. (Dr. K. Tomita, now Professor of Tokai University, and Dr. H. Kondo and Dr. K. Nagata) for the donation of diaphorase and their helpful suggestion on diaphorase catalysis.

\section{References}

1. V. J. Razumas, J. J. Kulys and A. A. Maliauskas, Anal. Chim. Acta, 117, 387 (1980).

2. H. T. Tang, C. E. Lunte, H. B. Halsall and W. R. Heineman, Anal. Chim. Acta, 214, 187 (1988).

3. I. Rosen and J. Rishpon, J. Electroanal. Chem. Interfacial Electrochem., 258, 27 (1989).

4. J. F. Frew, N. C. Foulds, J. M. Wilshere, N. J. Forrow and M. J. Green, J. Electroanal. Chem. Interfacial Electrochem., 266, 309 (1989).

5. N. C. Foulds, J. E. Frew and M. J. Green, "Biosensors. $A$ Practical Approach", ed. A. E. G. Cass, p. 105, Oxford University Press, Oxford, 1990.

6. R. Q. Thompson, G. C. Barone III, H. B. Halsall and W. R. Heineman, Anal. Biochem., 192, 90 (1991).

7. J. Heyrovsky and J. Kuta, "Principle of Polarography", p. 380, Academic Press, New York, 1966.

8. P. Zuman, "Organic Polarographic Analysis", p. 17, Pergamon Press, Oxford, 1964.

9. S. Todoriki, K. Miki, T. Ikeda and M. Senda, Denki Kagaku, 58, 1089 (1990) and the papers cited therein.

10. S. Ozawa, T. Ikeda and M. Senda, paper presented at the International Congress on Analytical Sciences, Chiba, August 25 - 31 (1991), Anal. Sci., 7, Supplement, in press.

11. to be published elsewhere.

12. M. Maeda, A. Tsuji, K. H. Yang and S. Kamada, paper presented at the International Symposium on Bioluminescence and Chemiluminescence, September $10-13,1990$, Cambridge.

(Received September 24, 1991)

(Accepted November 12, 1991) 